\title{
Pyroxenite xenoliths record episodic metasomatism in deep lithosphere, northwestern North China Craton
}

\author{
HONG-Kun DaI ${ }^{1,2}$, JiAn-PING ZHENG ${ }^{1,2}$, WiLliam L. \\ GRIFFIN $^{1,2}$ SUZANNE Y. O'REILLY ${ }^{1,2}$, QING XIONG ${ }^{1,2}$ \\ ${ }^{1}$ GPMR, School of Earth Sciences, China University of \\ Geosciences, Wuhan, Hubei 430074, China \\ ${ }^{2}$ CCFS/GEMOC, Department of Environmental Sci., \\ Macquarie University, Sydney, NSW 2109, Australia
}

Geochemical data for newly-found pyroxenite xenoliths from the Langshan area (northwestern North China Craton) are integrated with a regional synthesis of deep-seated xenoliths to constrain the nature of lithospheric modification.

The Langshan pyroxenites are of two types, high- $\mathrm{Mg}^{\#}$ $\left[\mathrm{Mg}^{2+} /\left(\mathrm{Mg}^{2+}+\mathrm{Fe}^{2+}\right) * 100=\sim 90\right]$ olivine websterites with high equilibration $\mathrm{Ts}\left(880 \sim 970^{\circ} \mathrm{C}\right)$, and $\mathrm{low}^{-\mathrm{Mg}^{\#}}$ (70 to 80 ) plagioclase-bearing websterites with low Ts te $\left(550 \sim 835^{\circ} \mathrm{C}\right)$. The high-Mg\# pyroxenites show trade-off abundances of olivine and orthopyroxene, highly depleted bulk Sr-Nd $\left(\varepsilon_{\mathrm{Nd}}=+11.41,{ }^{87} \mathrm{Sr} /{ }^{86} \mathrm{Sr}=\sim 0.7034\right)$ and low clinopyroxene $\mathrm{Sr}$ isotopic ratios (mean ${ }^{87} \mathrm{Sr} /{ }^{86} \mathrm{Sr}=\sim 0.703$ ). They are interpreted to reflect reaction of mantle peridotites with silica-rich melts derived from the convective mantle. Their depletion in fusible components (e.g., $\mathrm{FeO}, \mathrm{TiO}_{2}$ and $\mathrm{Na}_{2} \mathrm{O}$ ) and progressive exhaustion of incompatible elements suggest melt extraction after their formation. The low- $\mathrm{Mg}^{\#}$ pyroxenites display layering, convex-upward rare-eart-element patterns, moderately enriched bulk $\mathrm{Sr}-\mathrm{Nd}$ isotopic ratios $\left(\varepsilon_{\mathrm{Nd}}=-14.20\right.$ $\left.16.74,{ }^{87} \mathrm{Sr} /{ }^{86} \mathrm{Sr}=0.7070 \sim 0.7078\right)$ and variable clinopyroxene Sr-isotope ratios $\left({ }^{87} \mathrm{Sr} /{ }^{86} \mathrm{Sr}=0.706-0.711\right)$. They are interpreted to be crustal cumulates from hypersthene-normative melts generated by interaction between asthenosphere and heterogeneous lithospheric mantle.

Integration with data for regional peridotite xenoliths, shows that the thinning and refertilisation of the lithospheric mantle was accompanied by crustal rejuvenation, and that such processes occurred episodically across northwestern NCC. A geodynamic model proposed for the evolution of the deep lithosphere includes long-term mass transfer through a mantle wedge into the deep crust from the Paleozoic to the Cenozoic, triggered by subduction of the Paleo-Asian ocean and the Late Mesozoic lithospheric extension of eastern Asia.

Dai et al. (2020) Pyroxenite xenoliths record episodic melt impregnation in the deep lithosphere of the northwestern North China Craton. Journal of Petrology, under review. 